\title{
PERUBAHAN PENGETAHUAN PEKERJA SEKS KOMERSIAL TENTANG HIV-AIDS MELALUI UPAYA PENDIDIKAN KESEHATAN METODE BRAIN STORMING
}

\author{
Ali Akbar ${ }^{1 *}$, Uti Rusdian Hidayat ${ }^{2}$, Suciarti Nurwijayanti $^{3}$ \\ 1.2.3. STIKes YARSI Pontianak \\ Ali Akbar: STIKes YARSI, Jl. Panglima A'im No. 1, \\ Pontianak, Kalimantan Barat, E-mail: fatihnya.alwi1806@gmail.com
}

\begin{abstract}
Abstrak
Pekerja seks komersial merupakan salah satu kelompok resiko yang memegang peranan penting dalam penyebaran HIV AIDS. Upaya yang cukup efektif untuk menekan penyebaran virus tersebut yaitu dengan meningkatkan pengetahuan pekerja mengenai perilaku seksual yang aman melalui metode pendidikan kesehatan yang sesuai.

Penelitian ini bertujuan untuk mengetahui pengaruh pendidikan kesehatan HIV AIDS dengan menggunakan metode brain storming terhadap perubahan pengetahuan pekerja seks komersial. Hasil analisis Simple Paired T Test menunjukkan ada perbedaan yang bermakna antara pengetahuan responden sebelum dan sesudah diberikan pendidikan kesehatan dengan metode brain storming ( $\mathrm{p}$ value $=0,000$ ).
\end{abstract}

Kata kunci : Pendidikan Kesehatan, HIV AIDS, Brain Storming, Pengetahuan

\begin{abstract}
Commercial sex workers are one of the risk groups that play an important role in the spread of HIV AIDS. Efficient efforts to suppress the spread of the virus are by increasing workers' knowledge of safe sexual behavior through appropriate health education methods.

This study aims to determine the effect of HIV AIDS health education using the brain storming method for changing knowledge of commercial sex workers. The results of the analysis of Simple Paired T Test showed that there were significant differences between the knowledge of the respondents before and after being given health education using the brain storming method ( $p$ value $=0,000$ ).
\end{abstract}

Keywords: Health Education, HIV AIDS, Brain Storming, Knowledge

\section{PENDAHULUAN}

Acquired Immune Deficiency Syndrome (AIDS) adalah sekumpulan gejala penyakit yang timbul karena turunnya kekebalan tubuh akibat infeksi virus yang disebut Human Immunodeficiency Virus (HIV). Akibat menurunnya kekebalan tubuh maka orang tersebut sangat mudah terkena berbagai penyakit infeksi (infeksi oportunistik) yang sering berakibat fatal. (Infodatin, 2014).
Laporan masalah perkembangan HIV AIDS di Indonesia oleh Kementrian Kesehatan RI (2017) pada Triwulan I menunjukkan bahwa dari bulan Januari sampai dengan Maret 2017 jumlah infeksi HIV yang dilaporkan sebanyak 10.376 orang. Persentase infeksi HIV tertinggi dilaporkan pada kelompok umur 25-49 tahun $(69,6 \%)$, diikuti kelompok umur 20-24 tahun $(17,6 \%)$, dan kelompok umur lebih dari 50 tahun $(6,7 \%)$. Sedangkan jumlah AIDS yang dilaporkan sebanyak 673 orang. Persentase 
AIDS tertinggi pada kelompok umur 30-39 tahun $(38,6 \%)$, diikuti kelompok umur 20-29 tahun $(29,3 \%)$ dan kelompok umur 40-49 tahun $(16,5 \%)$.

Berdasarkan data survei, kasus HIV tahun 2017 di Klinik VCT “ $X$ ” terdapat 75 orang yang terinfeksi HIV. Namun yang menjadi salah satu kelompok rentan untuk terjadinya penularan HIV AIDS adalah Pekerja Seks Komersial. Catatan jumlah Pekerja Seks Komersial pada bulan April 2017 terdapat 22 orang sedangkan pada bulan September 2017 menjadi 27 orang. Penambahan jumlah Pekerja Seks Komersial dapat memicu perkembangan mekanisme infeksi HIV. Di banyak kota, kelompok masyarakat dan sukarelawan turut berkontribusi membantu penderita AIDS. Jenis dan jumlah layanan bervariasi menurut lembaga dan kota, di antaranya tes dan konseling HIV, layanan klinik, sistem teman, kelompok pendukung, perawatan tangguh, pendidikan dan penjangkauan, layanan rujukan, dan perumahan. Selain itu, materi pendidikan dan kelompok pendukung juga tersedia melalui akses Internet (Ignatavicius, 2015).

Salah satu upaya yang dapat dilakukan untuk membantu mencegah penyebaran HIV-AIDS adalah dengan meningkatkan pengetahuan penderita dan kelompok rentan mengenai upaya pencegahan penyebaran melalui metode pendidikan kesehatan yang sesuai. Komisi Penanggulangan HIV dan AIDS (2015), menyatakan bahwa pemerintah melakukan pencegahan HIV AIDS dengan cara melakukan atau memberikan penyuluhan kepada masyarakat secara luas mengenai penyakit HIV AIDS. Kegiatan penyuluhan termasuk ke dalam salah satu cara penanganan penyakit HIV AIDS agar tidak semakin menjadi luas. Pembelajaran dan pendidikan kesehatan yang diberikan kepada masyarakat haruslah dijelaskan secara jelas dan mudah dimengerti.

Brain storming adalah metode yang dimodifikasi dari diskusi kelompok dan mempunyai prinsip yang sama dengan diskusi kelompok. Perbedaannya terletak pada permulaannya, dimana peserta diberikan suatu masalah dan peserta kemudian memberikan tanggapannya. Tanggapan atau jawaban tersebut ditampung dan ditulis dalam flipchart atau papan tulis, setelah semuanya mengemukaan pendapat, baru tiap anggota boleh berkomentar dan akhirnya terbentuklah diskusi (Notoatmodjo, 2010).

Penelitian Fauzatul (2016) menyimpulkan bahwa metode brain storming terbukti efektif terhadap motivasi dan hasil belajar pada pembelajaran tematik integratif sub tema kebersamaan dalam keberagaman peserta Madrasah Ibtidaiyah Negeri (MIN) Demangan yang dibuktikan dari hasil uji-t dengan signifikansi 0,000 pada kelompok eksperimen. 
Penelitian Yolantia (2016) juga menyimpulkan hal yang serupa bahwa terdapat pengaruh antara penggunaan metode brain storming dengan hasil belajar siswa pada materi keanekaragaman hayati kelas $\mathrm{X}$ di MAN 1 Meulaboh yang dibuktikan dengan hasil perolehan nilai $\mathrm{t}>\mathrm{t}(6,577>2,101)$ dan nilai $\operatorname{sig}<\lambda(0,000<0,025)$.

Adanya bukti peningkatan pengetahuan dan motivasi peserta didik dengan metode brain storming dapat dimanfaatkan semaksimal mungkin oleh perawat dalam memberikan pendidikan kesehatan pada pekerja seks komersial, mengingat pengetahuan mereka terkait HIV AIDS juga turut mempengaruhi penyebaran HIV AIDS, salah satunya melalui praktek hubungan seksual yang tidak aman.

Variasi perilaku beresiko dari pekerja seks komersial dan karakterstik tema pembelajaran menjadi alasan kuat dalam penggunaan metode brain storming pada pekerja seks komersial dengan harapan metode ini mampu menghadirkan proses pembelajaran yang efektif dengan meningkatkan partisipasi peserta didik dalam mencurahkan ide dan kemudian diarahkan pada konsep yang sesuai sebagai upaya untuk meningkatkan pengetahuan mereka.

\section{METODE}

Penelitian ini menggunakan desain quasi eksperimen yaitu rancangan pre and post test tanpa kelompok kontrol. Penelitian ini dilaksanakan pada tanggal 28 Juni - 29 Juni 2018 di Lounge Karoke "Y". Populasi dalam penelitian ini sebanyak 35 orang. Teknik sampling yang digunakan adalah non probability sampling dengan pengambilan secara sampling jenuh atau total sampling. Total sampel yang memenuhi kriteria dan terlibat dalam penelitian ini berjumlah 31 orang.

Brain storming dilakukan selama 70 menit yang dimulai dengan memberikan sebuah topik masalah atau bahan diskusi dan kemudian peserta diminta untuk memberikan jawaban atau tanggapan terkait masalah tersebut. Tanggapan atau jawaban dari tiap responden ditampung dan ditulis pada flipchart dan setelah semuanya mengemukakan pendapat maka terbentuklah diskusi.

Penilaian terhadap pengetahuan responden dilakukan dengan menggunakan kuisioner yang terdiri dari 14 pernyataan mengenai HIV AIDS yang dirancang oleh peneliti dan sudah dilakukan uji validitas dan reliabilitas terlebih dahulu pada tempat yang berbeda dalam satu wilayah dengan hasil uji valid > 0,3494 (r tabel) dan hasil uji reliabilitas 0,896 .

\section{HASIL}

Tabel 1. Distribusi Frekuensi Berdasarkan Pendidikan Responden di Lounge Karaoke "Y" (n =31)

\begin{tabular}{ccc}
\hline Karakteristik & $\mathrm{f}$ & $\%$ \\
\hline PENDIDIKAN & & \\
SD & 1 & 3,2 \\
SMP & 10 & 32,2 \\
SMA & 20 & 64,5 \\
\hline
\end{tabular}


Tabel 1 menunjukkan distribusi responden berdasarkan pendidikan terakhir yaitu sebagian besar responden pendidikan terakhir SMA sebanyak 20 orang $(64,5 \%)$, dan sebagian kecil responden pendidikan terakhirnya SD sebanyak 1 orang $(3,2 \%)$.

Tabel 2. Nilai Rerata Umur Responden di Lounge Karaoke "Y" (n=31)

\begin{tabular}{cccc}
\hline Karakteristik & $\mathrm{n}$ & Mean & $\begin{array}{l}\text { Min- } \\
\text { Max }\end{array}$ \\
\hline Umur & 31 & 23,55 & $16-28$ \\
\hline
\end{tabular}

Tabel 2 menunjukkan bahwa rerata umur responden berada pada angka 23,55 atau 24 tahun dengan usia terendah 16 tahun dan usia tertinggi 28 tahun.

Tabel 3. Perbandingan Rerata Skor Pengetahuan Responden Sebelum dan Sesudah Pendidikan Kesehatan di Lounge Karaoke "Y" $(n=31)$

\begin{tabular}{lcccc}
\hline Karakteristik & $\mathrm{n}$ & Mean & $\begin{array}{c}\text { Min- } \\
\text { Max }\end{array}$ & $\begin{array}{c}\mathrm{p} \\
\text { value }\end{array}$ \\
\hline Pre Test & 31 & 65,35 & $50-86$ & 0,000 \\
Post Test & 31 & 87,48 & $71-100$ & \\
\hline
\end{tabular}

Tabel 3 menunjukkan bahwa rerata pengetahuan responden tentang HIV AIDS sebelum dilakukan pendidikan kesehatan dengan metode brain storming yaitu 65.35 dengan skor pengetahuan terendah 50 dan skor pengetahuan tertinggi 86 , sedangkan rerata pengetahuan responden tentang HIV AIDS setelah dilakukan pendidikan kesehatan metode brain storming berada pada angka 87.48 dengan skor pengetahuan terendah 71 dan skor pengetahuan tertinggi 100 .

Hasil analisis menunjukkan terdapat perbedaan yang bermakna pada rerata skor pengetahuan responden sebelum dan sesudah diberikan pendidikan kesehatan dengan metode brain storming $(\mathrm{p}$ value $=0,000)$ sehingga dapat disimpulkan bahwa ada perubahan pengetahuan yang bermakna tentang HIV AIDS pada pekerja seks komersial melalui pendidikan kesehatan metode brain storming di Lounge Karoke "Y"

\section{PEMBAHASAN}

Kegiatan edukasi diperlukan untuk meningkatkan pengetahuan. Peningkatan pengetahuan sangat mungkin terjadi apabila seseorang terpapar dengan informasi baru, apalagi jika didukung dengan upaya yang terencana untuk mengubah pengetahuan individu dengan metode tertentu yang disesuaikan dengan karakteristik dan tujuan pembelajaran yang ingin dicapai.

Bentuk edukasi yang diberikan pada penelitian ini adalah pendidikan kesehatan menggunakan metode brain storming dengan harapan dapat memaksimalkan pengalaman belajar melalui peran serta responden dalam menyampaikan ide dan gagasan dalam proses pembelajaran. Selain itu responden juga belum pernah mendapatkan pendidikan kesehatan dengan metode curah pendapat atau brain storming.

Penelitian ini menunjukkan efektivitas pendidikan kesehatan dengan metode brain storming dalam meningkatkan pengetahuan responden tentang HIV AIDS yang dibuktikan dengan adanya peningkatan skor rata-rata 
pengetahuan responden setelah diberikan pendidikan kesehatan dengan metode brain storming dengan beda rerata skor pengetahuan sebesar 22.13 dan nilai $\mathrm{p}=0,000$.

Hasil penelitian ini memiliki kesamaan dengan penelitian yang dilakukan oleh Fauzatul (2016) dan Yolantia (2016) yang menyimpulkan adanya pengaruh penggunaan metode brain storming dengan hasil belajar dan motivasi siswa dengan nilai $\mathrm{p}<0,05$. Meskipun terdapat perbedaan dari karakteristik responden akan tetapi proses curah pendapat yang dilakukan pada metode brain storming memiliki pola yang sama dalam membantu dan mendukung tercapainya tujuan pembelajaran.

Perubahan pengetahuan yang terjadi pada penelitian ini dan beberapa penelitian serupa dapat disebabkan oleh adanya peran mereka selama proses belajar seperti pengumpulan sejumlah besar gagasan sebagai bagian dari strategi metode ini. Pengumpulan gagasan memungkinkan ide yang muncul lebih banyak dan beragam karena responden dengan bebas menyalurkan ide tersebut tanpa adanya kritik, selain itu responden juga dapat berpikir untuk menyatakan pendapat karena kreatifitas tidak dibatasi dan dapat meningkatkan kemampuan berpikir kreatif responden.

Penelitian ini sangat berguna dan bermanfaat untuk dilakukan secara berkelanjutan sesuai kebutuhan pembelajaran sebagai upaya meminimalisir dan menekan angka kejadian infeksi HIV AIDS.

\section{Keterbatasan}

Pada penelitian ini, peneliti tidak menggunakan kelompok kontrol sebagai pembanding dikarenakan adanya keterbatasan dari jumlah sampel penelitian. Penelitian selanjutnya dapat diarahkan pada tujuan eksplorasi pengalaman atau hambatanhambatan yang mungkin dirasakan oleh kelompok rentan dalam mencegah penyebaran virus HIV AIDS.

\section{KESIMPULAN}

Terdapat perbedaan skor pengetahuan pekerja seks komersial tentang HIV AIDS sebelum dan sesudah pendidikan kesehatan yaitu pre test 65.35 dan post test 87.48 dengan metode brain storming menunjukan perbedaan bermakna $\mathrm{p}$ value $=0,000$ yang berarti $\mathrm{Ha}$ diterima, karena adanya pengaruh pendidikan kesehatan HIV AIDS dengan menggunakan metode brain storming terhadap perubahan pengetahuan pekerja seks komersial di Lounge Karaoke "Y".

\section{Saran}

Peneliti menyarankan agar pendidikan kesehatan tentang HIV AIDS dengan metode brain storming dapat dilakukan secara berkelanjutan sebagai upaya pencegahan penyebaran virus maupun untuk mengarahkan kualitas hidup penderita dan kelompok rentan ke arah yang lebih baik. 


\section{UCAPAN TERIMA KASIH}

Penelitian ini dapat terlaksana berkat dukungan dan kerjasama dari berbagai pihak, oleh karena itu kami sampaikan terima kasih kepada :

1. Ibu Fajar Yousriatin, M. Kes selaku Ketua STIKes YARSI Pontianak yang telah memberikan dukungan dalam proses pengajuan permohonan dan perizinan tempat penelitian.

2. Ketua Lembaga Penelitian dan Pengabdian Masyarakat (LPPM) STIKes YARSI Pontianak yang telah banyak membantu serta memfasilitasi publikasi hasil penelitian ini.

3. Pimpinan dan seluruh jajaran Lounge Karaoke "Y" yang telah memberikan izin dan memfasilitasi pelaksanaan penelitian.

4. Seluruh responden yang sudah bersedia terlibat dalam proses penelitian ini.

\section{REFERENSI}

A.Samik, Wahab. (2002). Sistem Imun, Imunisasi, dan Penyakit Imun. Jakarta: Widya Medika

Alimul Hidayat, Aziz. (2009). Pengantar Konsep Dasar Keperawatan. Jakarta: Salemba Medika

Aru W, Sudoyo. (2009). Buku Ajar Ilmu Penyakit Dalam. Jilid II. Edisi V. Jakarta: Interna Publishing

Dharma, Kusuma, K. (2011). Metodologi Penelitian Keperawatan : Panduan Melaksanakan dan Menerapkan Hasil Penelitian. Jakarta: Trans InfoMedia
Fauzhatul, M. (2016). Pengaruh Metode Brain Storming Terhadap Motivasi dan Hasil Belajar Pada Pembelajaran Tematik Integratif, 4(2).

Ignatavicius, D.D. and Workman, M.L. (2015). Medical Surgical Nursing : Patient Centered Collaborative Care. $8^{\text {th }}$ Ed. St. Louis : Elsevier Saunders

Katiandagho, Desmon. (2015). Epidemiologi HIV AIDS. Bogor: In Media

Kementrian Kesehatan RI. Laporan Perkembangan HIV AIDS dan Penyakit Infeksi Menular Seksual. Jakarta: 2017. Minnah. (2012). Pola Pikir dan Pendidikan. Jakarta: EGC

Notoatmodjo, S. (2010). Promosi Kesehatan Teori dan Aplikasi. Jakarta: Rineka Cipta Padila. (2012). Buku Ajar Keperawatan Medikal Bedah. Yogyakarta: Nuha Medika

Simanjuntak. (2010). Perbandingan Pengetahuan dan Sikap Antara Remaja Putra dan Remaja Putri Tentang Pencegahan HIV AIDS. 2 (2). 